\title{
PENANAMAN PENDIDIKAN KARAKTER CINTA LINGKUNGAN MELALUI JARI KREASI SAMPAH BOCAH CILIK DI KAWASAN PARANGTRITIS
}

\author{
Yora Harlistyarintica, Hana Wahyuni, Widiyawanti, \\ Nur Yono, Indah Permata Sari, dan Nur Cholimah, M.Pd \\ PAUD FIP Universitas Negeri Yogyakarta \\ yora.harlistya@gmail.com,hanawahyuni225@gmail.com,wantiwidiya@gmail.com, \\ nuryono.ion@gmail.com,indah1502@yahoo.com,nurcholimah@uny.ac.id
}

\begin{abstract}
Abstrak
Pelatihan ini bertujuan untuk menanamkan karakter cinta lingkungan pada anak-anak usia 412 tahun di kawasan wisata Parangtritis. Usia tersebut merupakan usia emas dalam tumbuh kembang anak yang memungkinkan adanya penanaman karakter cinta lingkungan. Metode yang digunakan dalam pelatihan ini berupa bermain, bercerita, menyanyi dan demonstrasi. Kegiatan yang dilakukan berupa eksplorasi sampah, outbond, pembuatan kerajinan (gelas plastik, tutup botol dan botol) dan lomba kreasi sampah. Sasaran kegiatan ini berjumlah 30 anak dari wilayah Parangtritis. Pendidik dalam kegiatan ini yaitu tim pelaksana program kreativitas mahasiswa Jari Kreasi Sampah Bocah Cilik. Hasil dari kegiatan ini anak mampu membuat kreasi sampah sebagai wujud rasa cinta terhadap lingkungan. Kreasi tersebut berupa boneka kelinci, boneka tutup botol, boneka laba-laba, dan lukis botol. Anak-anak terlihat antusias selama mengikuti kegiatan. Orang tua sangat mendukung kegiatan ini terlihat dari keterlibatannya dalam mendampingi anak.
\end{abstract}

Kata kunci: karakter, cinta lingkungan, sampah, anak

\section{CULTIVATING THE LOVING ENVIRONMENT CHARACTER EDUCATION THROUGH FINGER KIDS' TRASH CREATION IN PARANGTRITIS AREA}

\begin{abstract}
This training aims to stimulate the love character towards environment for children age 4-12 years old in Parangtritis tourism area. At age 4-12, children area in the best stage to be accustomed to love and care to their environment. The methods used to build the character are playing, story telling, singing and demonstrating. The activities are waste exploration, outbond, handicraft production (plastic cups, bottle caps, and bottles) and waste creation contest. The creation could be in the form of rabbit doll, bottle cap doll, spider doll, and bottle painting. The targets are 30 children around Parangtritis area. The educators of this activitity are the implementer team from Program Kreativitas Mahasiswa Jari Kreasi Sampah Bocah Cilik. The program outcome is to educate children to love their environment by making waste creation. Children are enthusiastic while their parents accompany them during activities as a sign of their support to the program.
\end{abstract}

Keywords: character, love the environment waste, children

\section{PENDAHULUAN}

Karakter merupakan hal yang sangat penting dan mendasar bagi manusia. Karakter menjadi salah satu kekhasan manusia dibandingkan dengan makhluk hidup yang lainnya. Manusia yang berkarakter kuat dan baik secara individual maupun sosial ialah manusia yang memiliki moral, akhlak, dan budi pekerti yang baik. Menurut Zubaedi (2011: 1), manusia yang hidup tanpa karakter adalah manusia yang membinatang.

Mengingat betapa pentingnya karakter maka masyarakat umum juga memiliki peran dan tanggungjawab untuk menanamkan karakter yang baik melalui 
proses pembelajaran yaitu dengan adanya pendidikan karakter. Pendidikan karakter adalah suatu upaya yang dilakukan dengan sengaja untuk mengembangkan karakter yang baik (good character) berlandaskan kebajikan-kebajikan inti (core virtues) yang secara objektif baik bagi individu maupun masyarakat (Saptono, 2011: 23).

Pendidikan karakter merupakan upaya untuk membantu perkembangan jiwa anak baik lahir maupun batin, dari sifat alami menuju ke arah peradaban manusiawi yang lebih baik. Seperti anjuran orang tua yang diberikan kepada anaknya agar duduk dengan baik, tidak berteriak-teriak, tidak jahil, menghormati orang tua, saling tolongmenolong dengan teman, bertanggung jawab dengan pekerjaannya, dan lain-lain. Sehubungan dengan hal tersebut pendidikan karakter mengajarkan kepada manusia tentang tabiat, moral, tingkah laku maupun kepribadian yang baik (Fadlillah \& Khorida, 2013: 22). Hal ini menunjukkan bahwa di dalam pendidikan karakter harus diawali dengan tekad yang baik, dirasakan dan tidak hanya dipikirkan saja namun dilakukan.

Pendidikan karakter merupakan proses yang berkelanjutan dan tidak pernah berakhir (never ending process). Belangsung sejak manusia ada dan berakhir ketika manusia tiada. Pendidikan karakter sebagai suatu proses terpadu untuk menyiapkan generasi penerus bangsa, yang disesuaikan dengan kebutuhan manusia masa depan, berakar pada nilai filosofi dan nilai-nilai kultural bangsa Indonesia. Pendidikan harus menumbuhkembangkan filosofi dan pengamalan atas keseluruhan karakter bangsa ini secara utuh dan menyeluruh. Karakter bangsa dapat menjadi suatu perekat bangsa karena karakter mengandung unsur budaya yang digali dari bangsa tersebut. Karakter dapat menjadi ciri khas suatu bangsa.

Karakter juga dapat menjadi identitas bangsa dalam menjaga kelestarian lingkungan. Karakter cinta lingkungan adalah salah satu karakter yang menunjukkan manusia tersebut peduli terhadap lingkungan sekitarnya yang bisa ditunjukkan dengan sikap dan tindakan untuk selalu berupaya mencegah kerusakan pada alam sekitarnya (Azzet, 2013: 97). Ciri manusia yang cinta lingkungan akan bertindak sebagaimana cinta mereka terhadap sesama manusia. Cinta tersebut dapat ditunjukkan manusia dengan cara selalu menjaga dan mengelola lingkungannya.

Pendidikan karakter mendesak dilakukan karena terjadinya degradasi moral anak bangsa. Di era modern seperti saat ini banyak masalah yang terjadi dalam kehidupan masyarakat seperti banyaknya kerusakan lingkungan akibat sampah. Sampah merupakan sisa buangan dari kegiatan sehari-hari manusia maupun proses alam berupa bahan yang dapat terurai (organik) maupun tidak terurai (anorganik) oleh tanah. Sampah yang tidak dikelola dengan baik akan menimbulkan bau tidak sedap, menjadi sumber penyakit, pencemaran lingkungan, serta merusak keindahan. Selain itu, tanah yang tercemar oleh sampah anorganik akan merusak strukturnya sehingga menjadi kurang subur. Struktur tanah yang rusak dapat mempengaruhi produktivitas tumbuhan.

Permasalahan sampah di Yogyakarta dapat dijumpai di salah satu kawasan wisata yaitu Pantai Parangtritis. Ironisnya, sampah yang berserakan tersebut berasal dari sampah yang tidak hanya dibuang oleh masyarakat sekitar melainkan juga para pengunjung pantai. "Sampah pariwisata dulunya sampai menumpuk tidak muat kena angin masuk area sini, sampah tersangkut dan banyak menimbulkan bau," terang ketua pengelola Garduaction, Vika Wahyu Aji (www. jogja.tribunnews.com diakses pada 17 Oktober 2016 pukul 17.24 WIB).

Tidak hanya itu, perilaku membuang sampah di sungai juga menimbulkan dampak yang merugikan bagi masyarakat sekitar Parangtritis seperti saat terjadi banjir. "Sebanyak 2000 meter kubik sampah yang terbawa banjir sabtu malam (12/3/2016) dibersihkan oleh 800 
orang relawan dalam acara bersih pantai di sepanjang Pantai Parangkusumo Parangtritis (www.harianjogja.com diakses pada 17 Oktober 2016 pukul 16.28 WIB).

Kawasan wisata Pantai Parangtritis telah mempunyai pengelolaan sampah bernama Garduaction (Garbage Care and Education) yang beralamat di Dusun Mancingan RT 02, Parangtritis, Kretek, Bantul, Yogyakarta. Garduaction menjadi tempat bagi warga yang ingin menabung sampahnya. Kemudian para pemuda melalui Garduaction juga telah memiliki inisiatif untuk memanfaatkan sampah anorganik menjadi kerajinan seperti spotspot foto dan saat ini hanya menjadi tempat wisata yang mengedukasi pemanfaatan sampah bagi masyarakat khususnya orang dewasa.

Berdasarkan permasalahan tersebut, maka dilakukan tindakan preventif agar anak tidak terpengaruh oleh lingkungan sosial. Kegiatan ini dapat menumbuhkan rasa cinta terhadap lingkungan sejak dini. Proses internalisasi rasa cinta lingkungan dapat dimulai dengan memberikan keterampilan sederhana dan bermakna yang mudah dilakukan oleh anak yaitu memanfaatkan sampah anorganik menjadi kerajinan yang berguna. Keterampilan ini dapat diberikan melalui pembelajaran maupun permainan yang berhubungan dengan lingkungan. Anak juga perlu dibantu untuk memahami makna setiap aktivitas yang dilakukan.

Program Jari Kreasi Sampah Bocah Cilik menyediakan kegiatan berupa eksplorasi sampah, outbond, pembuatan kerajinan, pembuatan showroom kerajinan untuk memamerkan hasil karya anak-anak, dan pekan lomba kreasi sampah. Diharapkan, melalui kegiatan ini anak-anak akan mempunyai kegiatan positif dan memiliki rasa cinta terhadap lingkungan sehingga pengelolaan sampah khususnya sampah anorganik dapat lebih dimanfaatkan secara optimal. Selain itu, Garduaction sebagai tempat pengelolaan sampah dapat menjadi wisata edukasi sampah bagi anak-anak sekitar maupun para pengunjung wisata.

\section{KARAKTER ANAK PEDULI LINGKUNGAN}

Karakter peduli lingkungan perlu dibangun dalam diri anak. Karakter ini meliputi peduli lingkungan sosial dan lingkungan alam. Karakter peduli lingkungan sosial merupakan sebuah sikap dan tindakan yang menunjukkan upaya untuk memberikan bantuan baik moril maupun materil bagi orang lain yang membutuhkan. Sikap ini menunjukkan kepekaan terhadap kondisi sekitar.

Karakter peduli lingkungan alam merupakan sikap yang ditunjukkan dengan perbuatan menjaga lingkungan alam sekitarnya. Sikap ini juga ditunjukan dengan tindakan memperbaiki kerusakan lingkungan yang terjadi. Karakter ini membuat kelangsungan alam terjaga.

Kedua karakter ini perlu dibangun dalam diri anak-anak supaya dapat memiliki sikap yang peka terhadap lingkungan baik sosial dan alam. Karakter ini akan membuat anak mengerti kondisi sesama manusia dan lingkungan alamnya. Tak dapat dipungkiri kedua hal ini merupakan kesatuan yang berjalan beriringan (Azzet, 2013:96-97).

\section{SAMPAH}

Sampah merupakan hasil sampingan dari aktivitas manusia yang tidak terpakai (Sucipto, 2012:1). Hasil sampingan ini akan selalu bertambah seiring meningkatnya aktivitas yang dilakukan manusia. Sampah terdiri dari dua jenis yaitu organik dan anorganik. Sampah organik dapat terurai secara alami seiring berjalannya waktu berasal dari makhluk hidup seperti sampah sisa sayur-sayuran, daun-daun, buah, ranting, dan lain-lain. Sampah anorganik merupakan sampah yang tidak dapat terurai (membutuhkan waktu yang lama) seperti plastik, kaca, kaleng, logam, dan lain-lain. 
Pengelolaan sampah dapat dilakukan dengan sistem $3 \mathrm{R}$ yaitu reduce (mengurangi), reuse (menggunakan kembali), dan recycle (mendaur ulang). Program mengurangi dapat dimulai dari mengganti bahan-bahan anorganik menjadi bahan-bahan yang dapat diuraikan oleh lingkungan. Reuse yaitu menggunakan kembali barang-barang yang dapat digunakan berkali-kali seperti kantong plastik. Sampah juga dapat di daur ulang menjadi barang-barang yang bermanfaat seperti tas kantong plastik, bunga plastik, tempat pensil, taplak meja, dan lain-lain.

Pengelolaan sampah organik dapat dilakukan dengan pengomposan. Kompos merupakan pupuk organik berasal dari sampah organik yang dapat digunakan untuk meningkatkan kesuburan tanaman. Kompos dapat dimanfaatkan dalam kegiatan manusia khususnya dalam bidang pertanian.

\section{METODE KEGIATAN}

\section{Pra Pelaksanaan}

Pada tahap pra pelaksanaan dilakukan beberapa kegiatan yaitu menjalin kerjasama, membuat matrik kerja, menyiapkan materi, lesson plan, alat dan bahan, modul pembelajaran. Kerjasama dilakukan dengan Kepala Dukuh Parangtritis, Ketua RT 02 Dusun Mancingan, dan Ketua Garduaction melalui diskusi.

Pada tahap pra pelaksanaan ini juga dilakukan pengukuran terhadap pengetahuan awal anak mengenai sampah dan cara pemanfaatannya. Angket penilaian sikap juga dibagikan kepada orang tua anak di awal kegiatan untuk mengetahui bagaimana sikap awal anak sebelum kegiatan dilaksanakan.

\section{Pelaksanaan}

Pada tahap pelaksanaan dilakukan beberapa kegiatan yaitu eksplorasi sampah, outbond, pembuatan kerajinan, membuat showroom kerajinan, dan pekan lomba kreasi sampah. Eksplorasi sampah merupakan kegiatan pengenalan sampah kepada anak-anak melalui pengamatan terhadap lingkungan sekitar. Outbond dilakukan untuk memberi penguatan materi dengan cara bermain bersama dalam bentuk pos-pos. Pada tahap inti terdapat pembuatan kerajinan-kerajinan dari sampah anorganik (gelas plastik, tutup botol dan botol). Pembuatan showroom kerajinan bertujuan untuk memamerkan hasil kerajinan anak-anak. Kemudian ada pekan lomba kreasi sampah yang bertujuan untuk mengasah kreativitas anak-anak.

Pada tahap pelaksanaan program ini juga dilakukan pengamatan terhadap anak tujuannya adalah untuk mengetahui tingkat keterampilan anak khususnya yang terkait dengan pemanfaatan sampah.

\section{Metode Pembelajaran}

Selama pembelajaran berlangsung digunakan metode bercerita, bernyanyi, demonstrasi, dan bermain. Bercerita digunakan ketika menjelaskan bahaya dan dampak sampah bagi lingkungan. Bernyanyi digunakan untuk menguatkan ingatan anak tentang materi yang dipelajari. Demonstrasi digunakan untuk menjelaskan cara membuat kerajinan sampah sekaligus anak ikut mempraktekkan. Bermain menjadi metode yang menarik bagi anak dalam belajar sehingga tidak membosankan.

\section{Sasaran Program}

Sasaran program ini adalah anakanak usia 4-12 tahun (PAUD sampai SD) yang berjumlah 30 anak dan berada di kawasan wisata Pantai Parangtritis Yogyakarta.

\section{Evaluasi dan Tindak Lanjut}

Evaluasi bertujuan untuk mengetahui apakah sudah sesuai antara perencanaan dan pelaksanaan. Evaluasi dilakukan dengan cara membandingkan tingkat penegtahuan dan sikap anak sebelum mengikuti program dengan hasilnya setelah mengikuti program. Apabila hasilnya meningkat maka melalui program ini rasa 
cinta lingkungan sudah mulai tumbuh pada anak-anak. Evaluasi ini juga dilakukan dengan melakukan tanya jawab dengan pihak-pihak yang terkait dengan permasalahan yang dihadapi pada pelaksanaan program ini. Hasil evaluasi dapat digunakan sebagai pertimbangan untuk menjalin kerjasama dengan mitra usaha dalam rangka menindaklanjuti program supaya kegiatan Jari Kreasi Sampah Bocah Cilik menjadi semakin berkembang. Tingkat kebermanfaatan kegiatan ini diungkapkan dengan adanya testimoni dari anak-anak, orang tua peserta Jari Kreasi Sampah Bocah Cilik, Pengelola Garduaction, dan masyarakat.

\section{HASIL PKM DAN PEMBAHASAN}

\section{Hasil Pelaksanaan Kegiatan}

Hasil Program Kreativitas

Mahasiswa bidang Pengabdian Kepada Masyarakat (PKM-M) melibatkan sasaran sebanyak 30 anak berusia 4-12 tahun. Berikut deskripsi kegiatannya:

\section{Kegiatan pertama}

Eksplorasi sampah merupakan kegiatan yang bertujuan mengedukasi jenis-jenis sampah yang terdapat di lingkungan sekitar kepada anak-anak. Metode yang digunakan yaitu pengamatan langsung terhadap lingkungan sekitar. Kegiatan ini dilaksanakan pada tanggal 29 April 2017.

Eksplorasi diawali dengan perkenalan diri dilanjutkan dengan tanya jawab mengenai sampah, jenis sampah dan cara memanfaatkan sampah. Kemudian untuk menambah semangat anak-anak diajarkan jargon yang berbunyi "lindungi lingkungan dengan kreasimu". Jargon dilakukan dengan gerakan tertentu. Kegiatan inti dilakukan dengan membagi anak dalam kelompok-kelompok kecil yang terdiri dari 3-4 orang. Setiap kelompok diberikan tugas untuk mencari jenis sampah di lingkungannya yang dapat dibuat kerajinan. Waktu yang diberikan selama 15 menit. Kemudian masing-masing kelompok menceritakan jenis sampah yang diperoleh di depan teman-temannya. Tim pelaksana PKM Jari Kreasi Sampah Bocah Cilik berfungsi sebagai pendidik yang menjelaskan cara pemanfaatan sampah tersebut serta menunjukkan contoh hasil kerajinan sampah. Kegiatan penutup dilakukan dengan menanyakan ulang (recalling) kepada anak-anak mengenai jenis sampah yang bisa dibuat kerajinan. Namun sebelumnya dilakukan pembagian angket sikap kepada anak yang harus diisi oleh orangtua anak dan dikumpulkan pada pertemuan selanjutnya.

\section{Kegiatan kedua}

Outbond bertujuan untuk memberikan penguatan materi tentang sampah melalui permainan. Kegiatan ini dilaksanakan pada tanggal 30 April 2017. Permainan dilakukan secara berkelompok yang terdiri dari 2 pos. Permainan yang dilakukan yaitu benar salah dan tebak gambar sampah.

Permainan pertama yaitu benar salah. Permainan ini menjelaskan pengertian sampah, jenis-jenis sampah, dan dampak sampah. Permainan dilakukan dengan memberikan beberapa pertanyaan yang langsung dijawab oleh kelompok secara bersamaan. Cara menjawab pertanyaan ini yaitu jika menjawab "benar" maka anak bergeser ke "kanan" namun apabila menjawab "salah" maka anak-anak bergeser ke "kiri". Jawaban diberikan setelah penjaga pos selesai membacakan pertanyaan.

Permainan kedua yaitu tebak gambar sampah. Permainan ini dilakukan dengan cara perkelompok mendengarkan cerita secara bersamaan, kemudian mengisi titiktitik dalam pertanyaan. Titik-titik di isi dengan cara menempelkan gambar ke papan yang telah disediakan.

Kegiatan penutup yaitu recalling mengenai makna permainan yang dilakukan. Dilakukan dengan mengumpulkan semua kelompok menjadi satu. Kemudian menanyakan apa yang dirasakan anak setelah bermain. Anak-anak 
juga ditunjukkan kerajinan yang sudah jadi serta alat dan bahan yang dibutuhkan dalam membuat kerajinan tersebut.

\section{Kegiatan ketiga}

Kegiatan ini dilaksanakan pada tanggal 06 Mei 2017. Kegiatan yang dilakukan adalah pembuatan kerajinan berdasarkan tema dengan metode demonstrasi. Tema yang pertama adalah tema gelas plastik. Pada tema ini, Tim Pelaksana PKM membuat kerajinan berupa boneka kelinci. Alat dan bahan yang dibutuhkan yaitu gelas plastik, lem kayu, kain flanel, cat pylox, kertas karton, pensil, mata boneka, dan sedotan. Berikut tahapan pembuatannya: 1) cuci gelas plastik dengan air mengalir dan gunakanlah sabun; 2) keringkan gelas plastik menggunakan kain;

3) beri warna gelas plastik dengan cat pylox; 4) buatlah pola telinga dan hidung dari kertas karton; 5) jiplaklah ke kain flanel, lalu gunting kain flanel tersebut; 6) buatlah kumis kelinci dari sedotan, dan 7) tempelkan telinga, hidung, mata, dan kumis ke gelas plastik hingga membentuk seperti kelinci.

\section{Kegiatan keempat}

Kegiatan ini dilaksanakan pada tanggal 07 Mei 2017. Kegiatan yang dilakukan adalah pembuatan kerajinan berdasarkan tema dengan metode demonstrasi. Tema yang kedua adalah tema tutup botol. Pada tema ini, Tim Pelaksana PKM membuat kerajinan berupa boneka tutup botol dan boneka laba-laba. Alat dan bahan yang dibutuhkan yaitu tutup botol, lem kayu, kain flanel, mata boneka, kertas karton, pensil dan penggaris. Berikut tahapan pembuatannya 1) cuci tutup botol dengan air mengalir dan gunakanlah sabun;

2) keringkan tutup botol menggunakan kain; 3) buatlah pola tutup botol; 4) setelah itu ukurlah lebar samping botol menggunakan penggaris untuk dibuatkan pola menggunakan kain flanel; 5) buatlah pola kaki laba-laba di kertas karton, lalu guntinglah kertas karton tersebut; 6) jiplaklah pola tersebut di atas kain flanel dan guntinglah; 7) kemudian untuk membuat boneka tutup botol buatlah pola di atas karton membentuk pakaian orang lalu jipaklah diatas kain flanel dan guntinglah dan 8) tempelkan pola- pola tersebut di tutup botol.

\section{Kegiatan kelima}

Kegiatan ini dilaksanakan pada tanggal 13 Mei 2017. Kegiatan yang dilakukan adalah pembuatan kerajinan berdasarkan tema dengan metode demonstrasi. Tema yang ketiga adalah tema botol. Pada tema ini, Tim Pelaksana PKM membuat kerajinan berupa lukis botol. Alat dan bahan yang dibutuhkan yaitu botol plastik, lem kayu, spidol permanen, dan glitter.

Cara membuat kerajinan tersebut yaitu 1) cuci gelas plastik dengan air mengalir dan gunakanlah sabun; 2) buatlah gambar di atas gelas plastik menggunakan spidol permanen; 3) berilah lem pada gambar tersebut dan 4) taburkanlah gliter di atas lem tersebut.

\section{Kegiatan keenam}

Kegiatan ini dilaksanakan mulai tanggal 14 Mei 2017. Kegiatan yang dilakukan adalah pembuatan showroom kerajinan. Kegiatan ini melibatkan ketua RT 02 Dusun Mancingan Pembina Garduaction, Warga Dusun Mancingan sebanyak dua orang serta Tim Pelaksana PKM. Pembuatan showroom kerajinan ini bertujuan untuk tempat memajang hasil karya anak-anak.

\section{Kegiatan ketujuh}

Kegiatan ini dilaksanakan pada tanggal 27 Mei 2017. Kegiatan yang dilakukan adalah pekan lomba kreasi sampah. Kegiatan ini diawali dengan bernyanyi bersama, dilanjutkan dengan lomba yang dibagi ke dalam tiga kategori lomba yaitu:
a. Kategori TK, membuat kerajinan bertema tutup botol.
b. Kategori SD kelas 1-3, membuat kerajinan bertema gelas plastik. 
c. Kategori SD kelas 4-6, membuat kerajinan bertema botol.

Setelah kegiatan lomba, dilanjutkan dengan menghias showroom kerajinan menggunakan cat (finger painting). Kemudian kegiatan diakhiri dengan pengumuman lomba dan penyerahan hadiah.

\section{Kegiatan kedelapan}

Kegiatan ini dilaksanakan pada tanggal 04 Juni 2017. Kegiatan yang dilakukan adalah penguatan materi, tanya jawab mengenai sampah dan pemanfaatannya, menuliskan kesan pesan, pemberian sertifikat, dan evaluasi kegiatan bersama Ketua RT 02 Dusun Mancingan, Pembina Garduaction dan Orang tua peserta Jari Kreasi Sampah Bocah Cilik.

\section{PEMBAHASAN}

Sikap karakter cinta lingkungan sebaiknya ditanamkan sejak usia dini dikarenakan karakter ini membutuhkan sebuah proses internalisasi sehingga ketika dewasa kelak memiliki sikap peduli lingkungan disekitarnya dalam hal ini sampah. Misalnya seperti yang terjadi di Kawasan Wisata Pantai Parangtritis Yogyakarta yang semakin hari sampah semakin menumpuk.

Fakta lain yang ditemukan oleh Tim Pelaksana PKM adalah bahwa kegiatan semacam ini belum pernah ada yaitu seperti melibatkan anak-anak dalam memanfaatkan sampah untuk dibuat sebuah kerajinan sederhana. Hal tersebut dapat dimaklumi sebagai akibat karena kesibukan warganya yang telah disibukkan oleh kegiatan usaha kecil menengah.

Dengan demikian program jari kreasi sampah bocah cilik dapat menumbuhkan rasa cinta terhadap lingkungan sejak usia dini. Selanjutnya program ini lebih menekankan bagaimana cara memanfaatkan sampah yang tidak dapat terurai (anorganik) untuk dimanfaatkan menjadi sebuah kerajinan.

Sebelum masuk pada kegiatan membuat sebuah kerajinan anak-anak diberikan penguatan materi tentang sampah seperti pengertian sampah, dampak positif dan negatif adanya sampah serta cara memanfaatkan sampah. Kegiatan tersebut dilakukan dengan cara mengamati lingkungan sekitar sambil bermain.

Dampak dari kegiatan ini dapat dilihat dari perkembangan kognitif, afektif dan psikomotorik pada anak. Perkembangan kognitif merupakan kemampuan anak untuk berpikir komplek serta kemampuan melakukan penalaran dan pemecahan masalah (Wiyani, 2013: 72). Salah satu contoh kegiatan untuk meningkatkan pengetahuan anak adalah eksplorasi sampah.

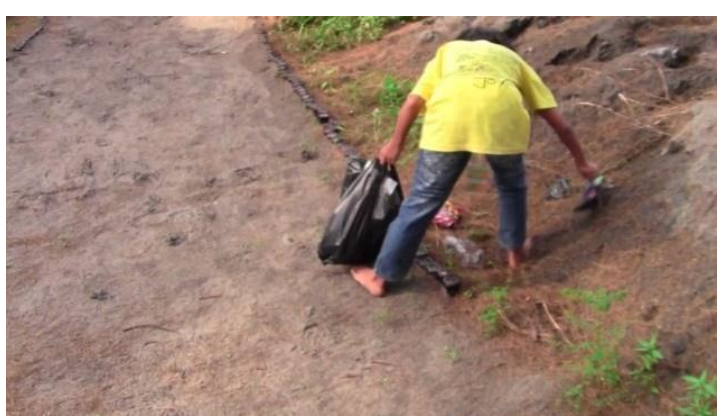

Gambar 01.

Anak-anak sedang mengambil sampah dalam kegiatan Eksplorasi Sampah

Sebelum melakukan kegiatan eksplorasi diadakan tanya jawab dengan anak tentang sampah dan pemanfaatannya yang bertujuan untuk mengukur kemampuan awal anak dari aspek pengetahuannya. Kemudian untuk mengukur pemahaman akhir anak tanya jawab dilakukan kembali pada akhir kegiatan. Berikut tingkat pengetahuan anak sebelum mengikuti program: 


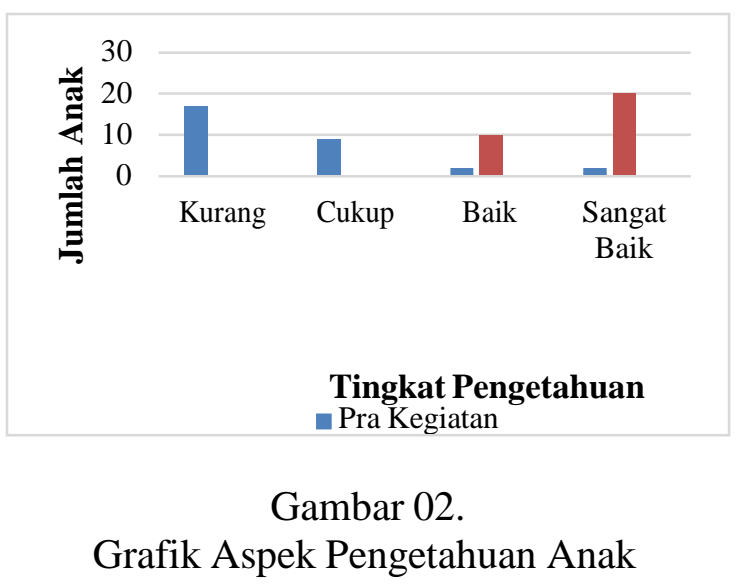

Berdasarkan grafik aspek pengetahuan anak tersebut dapat dijelaskan bahwa tingkat pengetahuan anak tentang sampah dan pemanfaatannya mengalami kenaikan. Sebelum mengikut program dari 30 anak tingkat pengetahuan anak didominasi masuk kedalam kategori cukup dan kurang. Namun, setelah mengikuti program tingkat pengetahuan anak meningkat sehingga berada pada kategori baik dan sangat baik.

Selain aspek pengetahuan aspek lain yang muncul pada anak selama program ini berlangsung adalah aspek keterampilan yang dapat ditunjukkan dari kegiatan yang melibatkan psikomotor anak. Perkembangan psikomotorik atau motorik merupakan perkembangan pengendalian gerakan tubuh melalui kegiatan pusat syaraf, urat syaraf, dan otot yang terkoordinasi (Hurlock, 2000: 150). Perkembangan motorik menunjukkan peningkatan keterampilan. Terdapat dua perkembangan motorik pada anak yaitu motorik kasar dan motorik halus. Gerak motorik kasar merupakan gerak anggota badan secara kasar atau keras seperti berjalan, berlari, melompat, melempar, dan lain-lain. Pada kegiatan ini diadakan permainan-permainan yang mendorong anak melakukan berbagai macam gerakan. Kegiatan outbond yang terdiri dari permaian benar salah dan tebak gambar sampah yang melibatkan seluruh anggota tubuh anak.

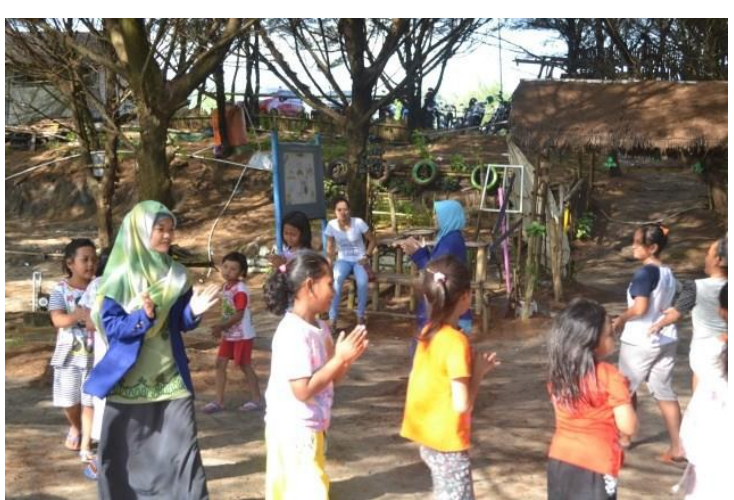

Gambar 03. Anak-anak sedang bernyanyi bersama dalam kegiatan Outbond

Gerak motorik halus merupakan keterampilan menggunakan media dengan koordinasi antara mata dan tangan (Wiyani, 2013: 66). Pada kegiatan ini dapat dilihat pada saat anak-anak membuat kerajinan sampah. Tim Pelaksana PKM membagi ke dalam tiga tema yaitu tema gelas plastik, tutup botol, dan botol. Pembagian tema tersebut didasarkan atas analisis kebutuhan terkait sampah yang paling banyak ditemukan di Kawasan Wisata Pantai Parangtritis Yogyakarta. Tahap-tahap pembuatan kerajinan melibatkan koordinasi mata dan tangan seperti menggunting, menempel, mengoleskan lem pada botol, menggambar dan memberikan pewarna.

Tim melakukan pengamatan kepada anak selama kegiatan berlangsung. Tujuannya adalah untuk mengamati bagaimana tingkat keterampilan anak. Dan hasilnya menunjukkan bahwa tingkat keterampilan anak didominasi pada kategori baik dan sangat baik. Berikut grafik hasil aspek keterampilan anak:



Gambar 04. Grafik aspek keterampilan anak 


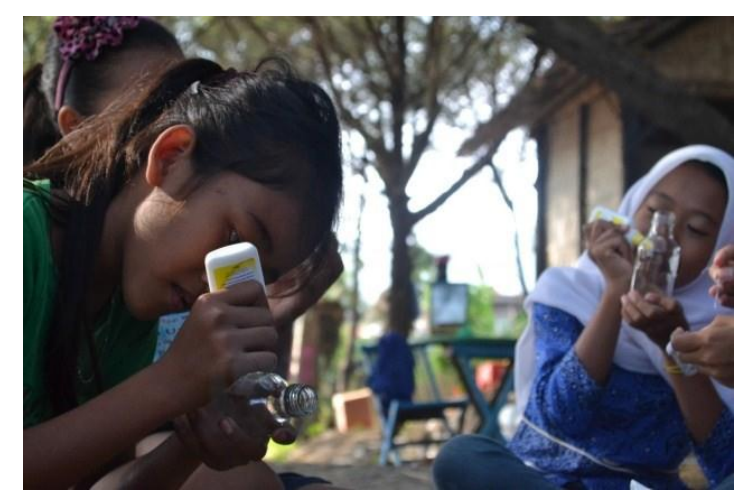

Gambar 05. Anak-anak sedang melukis botol dalam kegiatan lomba kreasi sampah

Nilai kreativitas memberikan anakanak kesenangan dan kepuasan pribadi yang berpengaruh terhadap perkembangan kepribadian (Hurlock, 199: 6). Salah satu kegiatan yang mengasah kreativitas anak yaitu terampil membuat kerajinan sampah. Hasil karya pembuatan kerajinan berupa boneka kelinci, boneka laba-laba boneka tutup botol dan lukisan botol.

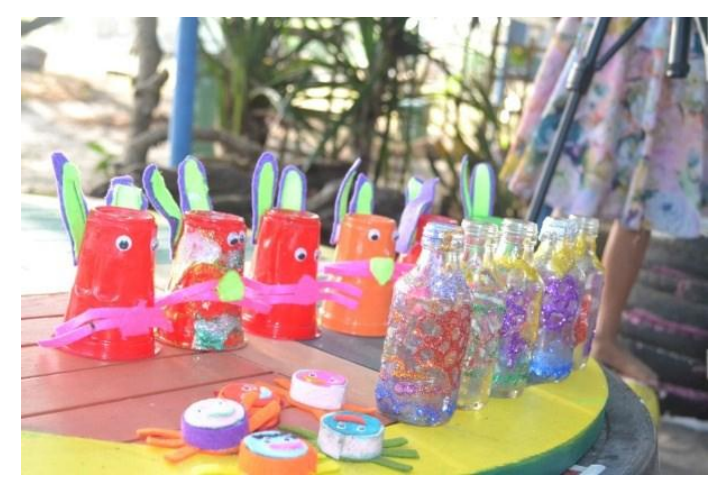

Gambar 05. Hasil karya anak-anak dalam kegiatan lomba kreasi sampah

Selain aspek pengetahuan dan sikap, program ini juga mampu mengembangkan aspek afektif anak. Perkembangan afektif pada anak merupakan perkembangan menyangkut perasaan anak, sikap, minat, emosi, nilai hidup (Poerwanti \& Widodo, 2002: 19). Pada kegiatan ini anak-anak mendapatkan nilai-nilai cinta lingkungan yang ditunjukkan melalui perubahan sikap setelah mengikuti kegiatan. Rasa cinta lingkungan dapat dilihat dari hasil angket sikap yang diisi oleh orang tua sebelum dan sesudah dilakukannya program. Orang tua anak menyatakan bahwa anak-anak sekarang melarang orang tuanya membuang sampah yang dapat dibuat kerajinan. Selain itu, anak-anak juga mempraktikkan materi yang diajarkan oleh tim PKM di rumah masing-masing bahkan menempelkan hasil karyanya di dinding rumah. Berikut hasil aspek sikap anak sebelum dan sesudah mengikuti program:



Gambar 06. Grafik Sikap Anak

Grafik sikap anak tersebut menunjukkan bahwa terjadi perubahan sikap anak. Sikap anak masuk kedalam kategori cukup sebelum mengikuti program. Namun, setelah mengikuti program sikap anak meningkat ke kategori baik dan sangat baik.

Kemudian, apresiasi hasil karya yang dilakukan oleh tim PKM yaitu dengan membuat showroom kerajinan di Garduaction. Tempat ini berfungsi untuk memamerkan hasil karya anak-anak. Garduaction yang merupakan tempat wisata juga menjadikan khalayak umum (pengunjung wisata) dapat melihat hasil karya anak.

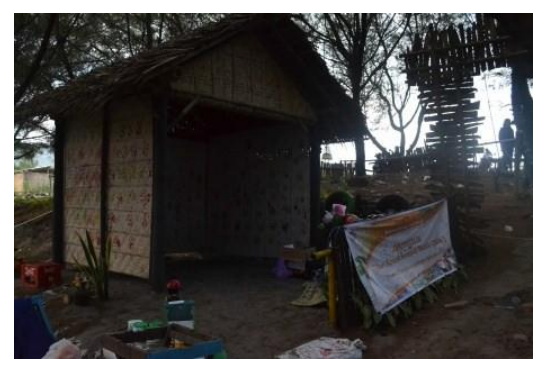

Gambar 06. Showroom kerajinan sebagai tempat memajang hasil karya anak-anak

Anak-anak juga belajar mengendalikan emosi ketika mengikuti 
kegiatan. Misalnya pada saat berlangsungnya kegiatan membuat kerajinan anak-anak yang usianya lebih tinggi dengan sabar menunggu teman yang usianya lebih rendah yang sedang menyelesaikan kerajinannya, selain itu anak-anak dengan sabar menyelesaikan karyanya tanpa meminta bantuan.

Kegiatan yang terakhir adalah pemberian sertifkat. Hal ini dimaksudkan untuk memberikan penghargaan pada anakanak yang telah mengikuti program Jari Kreasi Sampah Bocah Cilik.

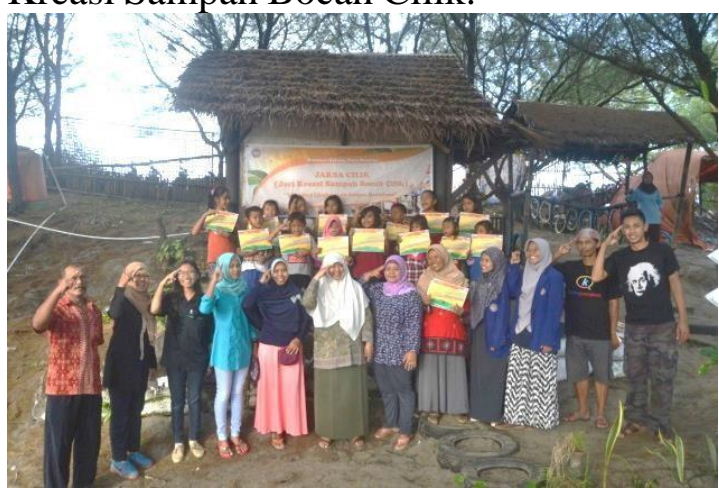

Gambar 07. Foto bersama dengan anakanak dan pihak-pihak terkait

Selama mengikuti kegiatan Tim Pelaksana PKM melakukan observasi pada anak-anak yaitu bahwa anak-anak sangat antusias mengikuti kegiatan. Hal ini terlihat pada saat berlangsungnya kegiatan seperti anak-anak banyak bertanya tentang kegiatan yang akan dan sedang berlangsung, menjawab pertanyaan ketika ditanya, menyelesaikan kegiatan membuat kerajinan dengan penuh kesabaran dan kreativitas serta berani menceritakan kegiatan yang telah dilakukan di depan teman-temannya. Selain itu anak-anak dapat mengikuti kegiatan sampai selesai.

\section{Faktor Pendukung Kegiatan}

Kegiatan PKM-Pengabdian Kepada Masyarakat berjudul Jari Kreasi Sampah Bocah Cilik terlaksana berkat kerjasama antar anggota Tim Pelaksana PKM, bimbingan Bapak/Ibu Dosen, kerjasama dengan pihak terkait seperti Bapak Dukuh dan Bapak RT 02 Dusun Mancingan, Bapak Pembina dan Ketua Garduaction, Orang
tua/Wali peserta Jari Kreasi Sampah Bocah Cilik dan masyarakat sekitar Garduaction. Tempat pelaksanaan PKM-Pengabdian Kepada Masyarakat bertempat di Garduaction yang didukung sepenuhnya oleh pihak terkait.

\section{Faktor Penghambat Kegiatan}

Terdapat peserta Jari Kreasi Sampah Bocah Cilik yang jarang hadir dikarenakan aktivitas lain seperti TPA.

\section{PENUTUP}

Program Jari Kreasi Sampah Bocah Cilik dapat menginternalisasi karakter cinta lingkungan pada anak-anak sejak usia dini. Hal tersebut dapat dilihat dari meningkatnya pengetahuan, keterampilan dan sikap anak setelah mengikuti program ini. Selain itu tingginya antusiasme anakanak dalam mengikuti kegiatan hingga selesai yang ditunjukkan dengan hasil karya berupa kerajinan sederhana yang dipajang di showroom kerajinan.

Perlu adanya kegiatan seperti Rumah Belajar bagi anak-anak khususnya dalam hal memanfaatkan sampah untuk dibuat kerajinan. 


\section{DAFTAR PUSTAKA}

Anasapriyadi. 2016. Garduaction

Parangkusumo, Tumpukan Sampah yang Diubah Jadi Wisata Edukasi oleh Pemuda Mancingan. (Online), (http://jogja.tribunnews.com, diunduh tanggal 17 Oktober 2016).

Azzet, Akhmad Muhaimin. 2013. Urgensi Pendidikan Karakter di Indonesia. Yogyakarta: Ar-Ruzz Media.

Fadlillah, Muhammad \& Lilif Mualifatu Khorida. 2013. Pendidikan Karakter Anak Usia Dini: Konsep \& Aplikasinya dalam PAUD. Yogyakarta: Ar-Ruzz Media.

Hurlock, Elizabeth B. 2000. Perkembangan Anak Jilid 1 Edisi 6. Jakarta: Erlangga.

Hurlock, Elizabeth B. 1999. Perkembangan Anak Jilid 2 Edisi 6. Jakarta: Erlangga.

Poerwanti, Endang \& Nur Widodo. 2002. Perkembangan Peserta Didik. Malang: UMM Press.

Priambodo, Yudho. 2016. 2000 Meter Kubik Sampah Diangkut dari Parangtritis. (Online), (http:// harianjogja.com, diunduh tanggal 17 Oktober 2016).

Sucipto, Cecep Dani. 2012. Teknologi Pengolahan Daur Ulang Sampah. Yogyakarta: Gosyen Publishing.

Saptono. 2011. Dimensi-dimensi Pendidikan Karakter Wawasan, Strategi, dan Langkah Praktis. Jakarta: Esensi.
Wiyani, Novan Ardy. 2013. Bina Karakter Anak Usia Dini: Panduan Orangtua \& Guru dalam Membentuk Kemandirian \& Kedisiplinan Anak Usia Dini. Yogyakarta: Ar-Ruzz Media.

Zubaedi. 2011. Desain Pendidikan Karakter, Konsepsi, dan Aplikasinya dalam Lembaga Pendidikan. Jakarta: Kencana. 